\title{
Synthesis, Characterization And Electrolytic Behavior Of Cadmium(II) Complexes Of 5,7,7,12,14,14- Hexamethyl-1,4,8,11-Tetraazacyclotetradeca-4,11- Diene And Isomers Of Its Saturated Analogue
}

\author{
Foni B. Biswas, MS \\ Department of Chemistry, Mawlana Bhashani Science and Technology \\ University, Santosh, Tangail, Bangladesh \\ Tapashi G. Roy, PhD \\ Saswata Rabi, MS \\ Department of Chemistry, University of Chittagong, Chittagong, Bangladesh \\ Mohammad K. Islam, DSc \\ Department of Chemistry, Mawlana Bhashani Science and Technology \\ University, Santosh, Tangail, Bangladesh
}

doi: 10.19044/esj.2016.v12n12p186 URL:http://dx.doi.org/10.19044/esj.2016.v12n12p186

\begin{abstract}
Condensation of ethylendiamine with acetone in the presence of quantitative amount of perchloric acid, yielded the ligand 5,7,7,12,14,14hexamethyl-1,4,8,11-tetraazacyclotetradeca-4,11-diene dihydroperchlorate (denoted by $\mathrm{L} .2 \mathrm{HClO}_{4}$ ). The ligand $\mathrm{L} .2 \mathrm{HClO}_{4}$ on reduction with $\mathrm{NaBH}_{4}$, yielded an isomeric mixture of saturated macrocycles, the $\mathrm{Me}_{6}[14]$ anes, which were resolved into two distinct C-chiral isomers (denoted by 'tet-a' and 'tet-b'). Interaction of ligands $\mathrm{L} \cdot 2 \mathrm{HClO}_{4}$, 'tet-a' and 'tet-b' with salts $\mathrm{CdI}_{2}, \mathrm{Cd}\left(\mathrm{NO}_{3}\right)_{2} \cdot 4 \mathrm{H}_{2} \mathrm{O}, \mathrm{CdCl}_{2} \cdot 2 \mathrm{H}_{2} \mathrm{O}$ and $\mathrm{Cd}\left(\mathrm{ClO}_{4}\right)_{2} \cdot 6 \mathrm{H}_{2} \mathrm{O}$ produced different five coordinated square pyramidal and six coordinated octahedral cdmium(II) complexes. Among them the complexes, cis-[Cd(teta) $\left.\left(\mathrm{NO}_{3}\right)\right]\left(\mathrm{NO}_{3}\right)$ and cis-[Cd(tet-b) $\left.\left(\mathrm{NO}_{3}\right)\right]\left(\mathrm{NO}_{3}\right)$ underwent axial ligand substitution reaction with KCNS; whereas complex $\left[\mathrm{Cd}\left(\right.\right.$ tet-a) $\left.\mathrm{I}_{2}\right]$ underwent axial ligand substitution reaction and complex $[\mathrm{CdLI}]\left(\mathrm{ClO}_{4}\right)$ underwent simultaneous ligand substitution and addition reaction with $\mathrm{NaNO}_{2}$. Characterization of all the complexes were carried out on the basis of elemental analysis; FT-IR, UV-Vis. and ${ }^{1} \mathrm{H}-\mathrm{NMR}$ spectroscopy; melting point determination as well as by magnetic moment and conductivity measurements. Molar conductivity measurment of the complexes reavealed that they show different electrolytic behavior in different solvents.
\end{abstract}


Keywords: Cadmium(II); Azamacrocyclic ligands; Square pyramidal complexes; Octahedral complexes; Electrolytic behaviour

\section{Introduction}

Great interest in the study of metal complexes with azamacrocyclic ligands is because of their importance in Supramolecular Chemistry, Material Chemistry and Biochemistry (Goher, et al., 1992; Boss, 1984; Escur, et al., 1996; Chandra and Kumar, 2004). The metal complexes containing synthetic tetraazamacrocyclic ligands have attracted a great deal of attention because they can be used as models for more intricate biological systems: metalloporphyrins (hemoglobin, myoglobin, cytochromes and chlorophylls), corrins (vitamin $\mathrm{B}_{12}$ ) and antibiotics (valinomycin, nonactin) (Radecka-Paryzek, et al., 2005; Alborés, et al., 2006; Mohapatra, et al., 2012; Ghachtouli, et al., 2006; Notni, et al., 2006; Suh, et al., 2006). Their (tetraazamacrocyclic ligands) specific complexation behavior is clearly of interest in many areas such as the design of complexes to act as medical imaging agents (Lauffer, 1987), act as effective antibacterial and antifungal agents (Biswas, et al., 2014; Sheikh, et al., 2010) and for the treatment of heavy metal intoxication in the case of metal poisoning (Hancock, et al., 1989; Hancock, et al., 1988).

In earlier study, Roy et al. (1999) prepared six-coordinate copper(II) complexes of octamethyltetraazacyclotetradecadiene of general formula $\left[\mathrm{Cu}\left(\mathrm{Me}_{8}[14]\right.\right.$ diene $\left.)\left(\mathrm{ClO}_{4}\right)_{\mathrm{m}} \mathrm{X}_{\mathrm{n}}\right]$, where $\mathrm{X}=\mathrm{NCS}^{-}, \mathrm{Cl}^{-}$or $\mathrm{NO}_{3}{ }^{-} ; \mathrm{m}=0$ or 1 and $\mathrm{n}=1$ 1or 2. In another study, Roy and coworkers (Roy, et al., 2007) prepared octahedral cis- and trans- cadmium(II) complexes with ligand, 3,10-C-meso$\mathrm{Me}_{8}[14]$ ane. The structure of compound cis- $\left[\mathrm{CdL} \mathrm{C}_{\mathrm{c}}\left(\mathrm{NO}_{3}\right)\right]\left(\mathrm{NO}_{3}\right)$ (where $\mathrm{L}_{\mathrm{c}}$ is one isomeric ligand of $\mathrm{Me}_{8}[14]$ ane) has been confirmed by X-ray crystallography (Roy, et al., 2010). Roy et al. (2011) reported synthesized a six-coordinate cobalt(III) complex of parent diene ligand ( $\mathrm{Me}_{6}[14]$ diene) of formula $\left[\mathrm{Co}\left(\mathrm{NO}_{2}\right)_{2}\left(\mathrm{C}_{16} \mathrm{H}_{32} \mathrm{~N}_{4}\right)\right]$ and has been confirmed by X-ray crystallography. Recently Yasmin et al. (2013) synthesized and characterized the complexes: [Cu( $\left.\left.\mathrm{Me}_{6}[14] \mathrm{ane}\right)\left(\mathrm{ClO}_{4}\right)_{2}\right],\left[\mathrm{Zn}\left(\mathrm{Me}_{6}[14] \mathrm{ane}\right)\left(\mathrm{NO}_{3}\right)_{2}\right]$ and $\left[\mathrm{Cu}\left(\mathrm{Me}_{6}[14]\right.\right.$ ane $\left.)\left(\mathrm{H}_{2} \mathrm{O}\right)\right] \mathrm{Cl} \mathrm{X}$-ray crystallography.

Detailed studies on cadmium(II) complexes of hexamethyltetraazacyclotetradecadiene $\left(\mathrm{L}^{2} 2 \mathrm{HClO}_{4}\right)$ and isomers of its saturated analouges ('teta' and 'tetb') were not reported so far. In our present study, new octahedral and square pyramidal cadmium(II) complexes of ligands L, 'tet-a' and 'tet-b' have been synthesized. Among them, four complexes also give their axial ligand substitution and addition products. Herein, synthesis, characterization and electrolytic behavior of the new cadmium(II) complexes have been reported. These complexes were found as 
very much effective antibacterial and antifungal agents as reported recently by our research group (Biswas, et al., 2014).

\section{Experimental section \\ Materials}

Ethylenediamine, absolute methanol (99.50\%, v/v), dimethyl sulfoxide (DMSO) and sodium borohydride were purchased from Merck, Germany. Perchloric acid (70\%, v/v), chloform, xylene and metal salts ( $\mathrm{CdI}_{2}$, $\mathrm{Cd}\left(\mathrm{NO}_{3}\right)_{2} \cdot 4 \mathrm{H}_{2} \mathrm{O}, \mathrm{CdCl}_{2} \cdot 2 \mathrm{H}_{2} \mathrm{O}, \mathrm{Cd}\left(\mathrm{ClO}_{4}\right)_{2} \cdot 6 \mathrm{H}_{2} \mathrm{O}, \mathrm{KCNS}$ and $\left.\mathrm{NaNO}_{2}\right)$ were purchased from Sigma-Aldrich, Munich, Germany. $\mathrm{KBr}$ was purchased from Flucka AG, Swizerland. The solvents were dried using standard literature procedures.

\section{Measurements}

Microanalysis (C, H, N, S analysis) of the complexes have been carried out on a C, H, N, S-analyzer at the Institut der Anorganische und Angewandte Chemie, Hamburg Universitaet, Germany. FT-IR spectra were taken as $\mathrm{KBr}$ discs in the range $4000-400 \mathrm{~cm}^{-1}$ on a Perkin-Elmer infrared spectrophotometer, Department of Chemistry, University of Chittagong, Bangladesh. Electronic absorption spectra were recorded on a Shimadzu UVVisible 265 spectrophotometer. ${ }^{1} \mathrm{H}$-NMR spectra were measured in $\mathrm{CDCl}_{3}$ and DMSO solution on a $400 \mathrm{MHz}$ NMR instrument at Bangladesh Council of Scientific and Industrial Research (BCSIR) laboratory, Dhaka, Bangladesh. Chemical shifts are given in ppm relative to tetramethylsilane as an internal reference. Conductance measurements of the metal complexes were done in chloroform, DMSO and water at $10^{-3} \mathrm{M}$ using a HANNA instrument equipped with a HI $8820 \mathrm{~N}$ conductivity cell. Magnetic measurements were carried out with a Gouy balance, calibrated against $\mathrm{Hg}\left[\mathrm{Co}(\mathrm{NCS})_{4}\right]$; susceptibilities were corrected for diamagnetic increments. Melting points of the complexes were measured on a Stuart SMP10 melting point (range: upto $300^{\circ} \mathrm{C}$ ) apparatus. For the determination of cadmium in complexes accurately weighed amounts of complexes were heated with a mixture of conc. $\mathrm{H}_{2} \mathrm{SO}_{4}, \mathrm{HNO}_{3}$ and $\mathrm{HClO}_{4}$ to convert cadmium complexes into cadmium(II) salts and then extracted into water. The solution was then titrated with a standard solution of $\mathrm{Na}_{2}$ EDTA using Xylenol orange as indicator.

\section{Synthesis}

Preparation of macrocycles: Synthesis of the ligand 5,7,7,12,14,14hexamethyl-1,4,8,11-tetraazacyclotetradeca-4,11-diene dihydroperchlorate $\left(\mathrm{L} .2 \mathrm{HClO}_{4}\right)$ and isolation of isomers of its saturated analogue ('tet-a' and 
'tet-b') were carried out according to the procedure adopted in literature (Busch, et al., 1971; Bembi, et al., 1984).

Preparation of new cadmium(II) complexes by direct reaction of ligands (L.2HClO ${ }_{4}$, 'tet-a' and 'tet-b') with different cadmium(II) salts

Proper weight $(1.0 \mathrm{mmol})$ of Cadmium(II) salts $\left(\mathrm{CdI}_{2}\right.$, $\mathrm{Cd}\left(\mathrm{NO}_{3}\right)_{2} \cdot 4 \mathrm{H}_{2} \mathrm{O}, \mathrm{CdCl}_{2} \cdot 2 \mathrm{H}_{2} \mathrm{O}$ or $\left.\mathrm{Cd}\left(\mathrm{ClO}_{4}\right)_{2} \cdot 6 \mathrm{H}_{2} \mathrm{O}\right)$ and ligands $(1.0 \mathrm{mmol})$ (L.2 $\mathrm{HClO}_{4}$, 'tet-a' or 'tet-b') were suspended/dissolved separately in $25 \mathrm{~mL}$ of hot methanol. The ligand solution/suspension was added as soon as possible to the salt solution while hot. The solution mixture was heated on a water bath and the volume of the solution reduced to $15 \mathrm{~mL}$. The solution was allowed to cool for one hour and the white solid product of cadmium(II) complex was filtered off, washed with methanol followed by diethyl ether and dried in a vacuum desiccator over silica gel.

[CdLI](ClO ${ }_{4}$ (1):Yield: $<85 \%$. m.p.: $>300^{\circ} \mathrm{C}$. Found: C, 31.11; H, 5.15; N, 9.02; Cd, 18.05. Calcd for $\mathrm{C}_{16} \mathrm{H}_{32} \mathrm{~N}_{4} \mathrm{CdIClO}_{4}$ : C, 31.03; H, 5.17; N, 9.05; Cd, $18.17 \%$.

trans-[Cd(tet-a)I $\boldsymbol{I}_{2}$ (2): Yield: $<80 \%$. m.p.: $>300^{\circ} \mathrm{C}$. Found: C, 30.01; $\mathrm{H}$, 5.51; N, 8.56; Cd, 17.29. Calcd for $\mathrm{C}_{16} \mathrm{H}_{36} \mathrm{~N}_{4} \mathrm{CdI}_{2}$ : C, 29.53; H, 5.54; N, 8.61; Cd, $17.29 \%$.

trans-[Cd(tet-b)I $\boldsymbol{I}_{2}$ (3): Yield: $<78 \%$. m.p.: $>300^{\circ} \mathrm{C}$. Found: C, 29.98; H, 5.49; N, 8.57; Cd, 17.27. Calcd for $\mathrm{C}_{16} \mathrm{H}_{36} \mathrm{~N}_{4} \mathrm{CdI}_{2}$ : C, 29.53; H, 5.54; N, 8.61; Cd, $17.29 \%$.

cis-[Cd(tet-a) $\left.\left(\mathrm{NO}_{3}\right)\right]\left(\mathrm{NO}_{3}\right)(4)$ Yield: $<70 \%$. m.p.: $>300^{\circ} \mathrm{C}$. Found: C, 36.78; H, 6.90; N, 16.12; Cd, 21.63. Calcd for $\mathrm{C}_{16} \mathrm{H}_{36} \mathrm{~N}_{6} \mathrm{CdO}_{6}$ : C, 36.89; $\mathrm{H}$, 6.92; N, 16.14; Cd, 21.59\%.

cis-[Cd(tet-b)(NO $\left.\left.\mathrm{NO}_{3}\right)\right]\left(\mathrm{NO}_{3}\right)$ (5): Yield: $<75 \%$. m.p.: $>300^{\circ} \mathrm{C}$. Found: C, 36.82; $\mathrm{H}, 6.89 ; \mathrm{N}, 16.12 ; \mathrm{Cd}, 21.61$. Calcd for $\mathrm{C}_{16} \mathrm{H}_{36} \mathrm{~N}_{6} \mathrm{CdO}_{6}$ : C, 36.89; H, 6.92; N, 16.14; Cd, 21.59\%.

[CdLCI]CI (6): Yield: $<80 \%$. m.p.: $>300^{\circ}$ C. Found: C, 31.11; H, 5.15; N, 9.02; Cd, 18.05. Calcd for $\mathrm{C}_{16} \mathrm{H}_{32} \mathrm{~N}_{4} \mathrm{CdCl}_{2}$ : C, 31.03; H, 5.17; N, 9.05; Cd, $18.17 \%$.

trans-[Cd(tet-a) $\left.\boldsymbol{C l}_{2}\right]$ (7): $\quad$ Yield: $<80 \%$. m.p.: $>300^{\circ} \mathrm{C}$. Found: C, 41.05; H, 7.71; N, 11.92; Cd, 24.15. Calcd for $\mathrm{C}_{16} \mathrm{H}_{36} \mathrm{~N}_{4} \mathrm{CdCl}_{2}: \mathrm{C}, 41.08 ; \mathrm{H}$, 7.70; N, 11.98; Cd, 24.05\%.

trans-[Cd(tet-b) $\left.\boldsymbol{C l}_{2}\right]$ (8): Yield: $<75 \%$. m.p.: $>300^{\circ} \mathrm{C}$. Found: C, 41.04; H, 7.69; N, 11.95; Cd, 24.17. Calcd for $\mathrm{C}_{16} \mathrm{H}_{36} \mathrm{~N}_{4} \mathrm{CdCl}_{2}$ : C, 41.08; H, 7.70; N, 11.98; Cd, 24.05\%.

[CdL(ClO $\left.\left.{ }_{4}\right)\right]\left(\mathrm{ClO}_{4}\right)$ (9): Yield: $<80 \%$. m.p.: $>300^{\circ} \mathrm{C}$. Found: C, 32.43; H, 5.39; N, 9.44; Cd, 19.12. Calcd for $\mathrm{C}_{16} \mathrm{H}_{32} \mathrm{~N}_{4} \mathrm{CdCl}_{2} \mathrm{O}_{8}$ : C, 32.47; $\mathrm{H}$, 5.41; N, 9.47; Cd, $19.01 \%$. 
[Cd(tet-a) $\left.\left(\mathrm{ClO}_{4}\right)_{2}\right]$ (10): Yield: $<80 \%$. m.p.: $>300^{\circ} \mathrm{C}$. Found: C, 32.20; H, 6.05; N, 9.38; Cd, 18.92. Calcd for $\mathrm{C}_{16} \mathrm{H}_{36} \mathrm{~N}_{4} \mathrm{CdCl}_{2} \mathrm{O}_{8}$ : C, 32.25; H, 6.04; N, 9.41; Cd, $18.88 \%$.

[Cd(tet-b) $\left.\left(\mathrm{ClO}_{4}\right)_{2}\right]$ (11): Yield: $<85 \%$. m.p.: $>300^{\circ} \mathrm{C}$. Found: C, 32.21; H, 6.07; N, 9.40; Cd, 18.95. Calcd for $\mathrm{C}_{16} \mathrm{H}_{36} \mathrm{~N}_{4} \mathrm{CdCl}_{2} \mathrm{O}_{8}$ : C, 32.25; H, 6.04; N, 9.41; Cd, 18.88\%.

Preparation of axial ligand substitution, axial substitution with anion exchange or simultanious addition \& substitution products of some cadmium(II) complexes

Proper weight $(1.0 \mathrm{mmol})$ of selected cadmium(II) complexes (cis$\left[\mathrm{Cd}\left(\right.\right.$ tet-a) $\left.\left(\mathrm{NO}_{3}\right)\left(\mathrm{NO}_{3}\right)\right], \quad$ cis-[Cd(tet-b) $\left.\left(\mathrm{NO}_{3}\right)\left(\mathrm{NO}_{3}\right)\right]$, cis-[CdLI]ClO 4 or trans-[Cd(tet-a) $\left.\left.\mathrm{I}_{2}\right]\right)$ and concerned salts $(2.0 \mathrm{mmol})\left(\mathrm{KCNS}\right.$ or $\left.\mathrm{NaNO}_{2}\right)$ were suspended/dissolved separately in $25 \mathrm{~mL}$ of hot methanol. The solution mixture was heated in a water bath and the volume of the solution reduced to $10 \mathrm{~mL}$. The solution was allowed to cool for three hours and the white solid product of cadmium(II) was filtered off, washed with methanol followed by diethyl ether and dried in a vacuum desiccator over silica gel.

[Cd(teta)(SCN)](SCN) (12): Yield: $<70 \%$. m.p.: $>300^{\circ}$ C. Found: C, 42.13; H, 7.04; N, 10.88; S, 12.48; Cd, 21.98. Calcd for $\mathrm{C}_{18} \mathrm{H}_{36} \mathrm{~N}_{6} \mathrm{CdS}_{2}$ : C, 42.15; H, 7.03; N, 10.93; S, 12.49; Cd, 21.94\%.

[Cd(tetb)(SCN)](SCN) (13): Yield: $<70 \%$. m.p.: $>300^{\circ} \mathrm{C}$. Found: C, 42.12; H, 7.03; N, 10.91; S, 12.49; Cd, 22.01. Calcd for $\mathrm{C}_{18} \mathrm{H}_{36} \mathrm{~N}_{6} \mathrm{CdS}_{2}$ : C, 42.15; H, 7.03; N, 10.93; S, 12.49; Cd, 21.94\%.

trans-[CdL $\left.\left(\mathrm{NO}_{2}\right)_{2}\right](14): \quad$ Yield: $<75 \%$. m.p.: $>300^{\circ} \mathrm{C}$. Found: C, 39.62; H, 6.58; N, 17.33; Cd, 23.26. Calcd for $\mathrm{C}_{16} \mathrm{H}_{32} \mathrm{~N}_{6} \mathrm{CdO}_{4}$ : C, 39.64; $\mathrm{H}$, 6.61; N, 17.34; Cd, 23.20\%.

trans-[Cd(tet-a) $\left.\left(\mathrm{NO}_{2}\right)_{2}\right]$ (15): Yield: $<75 \%$. m.p.: $>300^{\circ} \mathrm{C}$. Found: C, 39.28; H, 67.31; N, 17.18; Cd, 23.09. Calcd for $\mathrm{C}_{16} \mathrm{H}_{36} \mathrm{~N}_{6} \mathrm{CdO}_{4}$ : C, 39.31; $\mathrm{H}$, 7.37; N, 17.20; Cd, 23.01\%.

\section{Results and discussion}

Syntheses

The structures of $\mathrm{L}_{2} 2 \mathrm{HClO}_{4}$, 'tet-a' and 'tet-b' (Figure 1) were established as per literature (Busch, et al., 1971; Bembi, et al., 1984). 


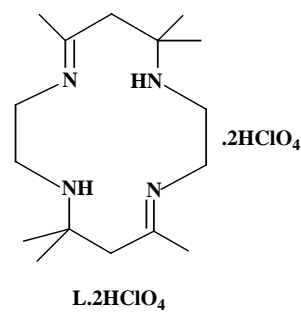

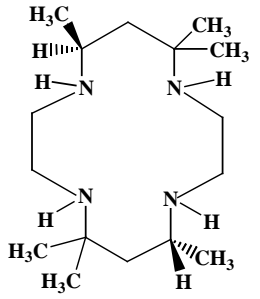

'tet-a'

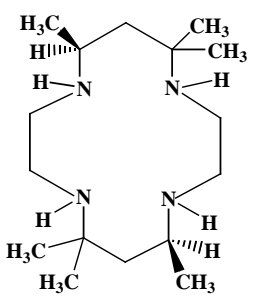

'tet-b'

Figure 1. Chemical structure of macrocyclic ligands L. $2 \mathrm{HClO}_{4}$, 'tet-a' and 'tet-b'.

Macrocyclic ligands $\mathrm{L}^{2} 2 \mathrm{HClO}_{4}$, 'tet-a' and 'tet-b' interact with salts $\mathrm{CdI}_{2}, \mathrm{Cd}\left(\mathrm{NO}_{3}\right)_{2} \cdot 4 \mathrm{H}_{2} \mathrm{O}, \mathrm{CdCl}_{2} \cdot 2 \mathrm{H}_{2} \mathrm{O}$ or $\mathrm{Cd}\left(\mathrm{ClO}_{4}\right)_{2} \cdot 6 \mathrm{H}_{2} \mathrm{O}$ in methanolic solution to produce six coordinated cis or trans cdmium(II) complexes and five coordinated square pyramidal complexes. The complexes cis-[Cd(teta) $\left.\left(\mathrm{NO}_{3}\right)\right]\left(\mathrm{NO}_{3}\right)$ and cis-[Cd(tet-b) $\left.\left(\mathrm{NO}_{3}\right)\right]\left(\mathrm{NO}_{3}\right)$ underwent axial ligand substitution and anion exchange reaction with KCNS to produce [Cd(teta)(SCN)](SCN) and [Cd(tet-b)(SCN)](SCN) respectively. The square pyramidal complex [CdLI] $\left(\mathrm{ClO}_{4}\right)$ underwent ligand substitution and addition reaction simultaniously with $\mathrm{NaNO}_{2}$ to produce trans-[CdL( $\left.\left(\mathrm{NO}_{2}\right)_{2}\right]$ and the complex trans-[Cd(tet-a) $\left.\mathrm{I}_{2}\right]$ underwent only axial ligand substitution reaction with $\mathrm{NaNO}_{2}$ to produce trans-[Cd(tet-a) $\left.\left(\mathrm{NO}_{2}\right)_{2}\right]$.

The compounds were characterized by elemental analysis, melting point determination, FT-IR (Table 1), UV-Vis. and ${ }^{1} \mathrm{H}-\mathrm{NMR}$ (Table 2) spectroscopy as well as by magnetochemical and conductivity measurement (Table 3).

The cadmium(II) compounds were found to be diamagnetic as expected for their $\mathrm{d}^{10}$ electronic configuration. The electronic spectra of these compounds do not exhibit $\mathrm{d}-\mathrm{d}$ bands, again as expected for $\mathrm{d}^{10}$ systems. Since infrared spectra of these compounds could not be run at wave numbers lower than $400 \mathrm{~cm}^{-1}$, IR bands due to same metal-ligand (axial) stretches could not be recorded. Conductance values of $0 \mathrm{ohm}^{-1} \mathrm{~cm}^{2} \mathrm{~mol}^{-1}$ in chloroform and 9-26 ohm ${ }^{-1} \mathrm{~cm}^{2} \mathrm{~mol}^{-1}$ in DMSO of some complexes supported the formation of non-electrolytic compounds. Molar conductivity values of 64-92 $\mathrm{ohm}^{-1} \mathrm{~cm}^{2} \mathrm{~mol}^{-1}$ of some complexes in DMSO indicate that the complexes are 1:1 electrolyte in nature. Figure 2 and Figure 3 represent the 
IR spectra of complex [CdLCl]Cl and ${ }^{1} \mathrm{H}-\mathrm{NMR}$ spectra of complex $[\mathrm{CdLI}]\left(\mathrm{ClO}_{4}\right)$ respectively.

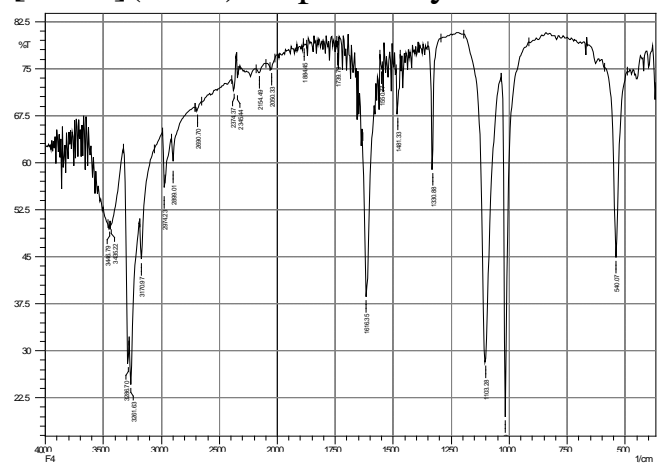

Figure 2. IR spectra of complex [CdLCl]Cl

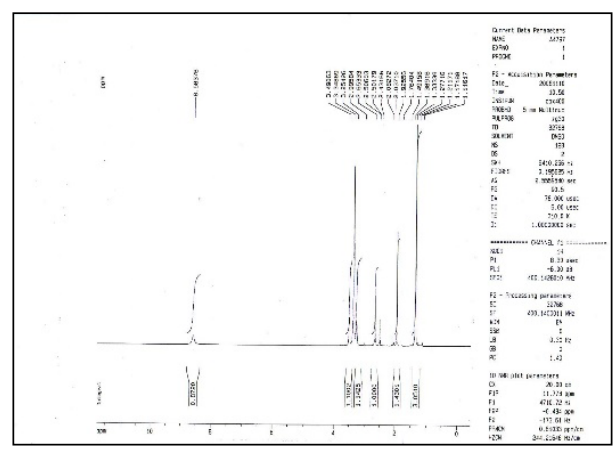

Figure 3. ${ }^{1} \mathrm{H}-\mathrm{NMR}$ spectra of complex cis$[\mathrm{CdLI}]\left(\mathrm{ClO}_{4}\right)$

\section{Compounds produced by direct reaction of ligands $\left(\mathrm{L} .2 \mathrm{HClO}_{4}\right.$, 'teta' and 'tetb') with cadmium(II) salts}

All the cadmium(II) complexes are white as expected. The infrared spectra of these compounds exhibit $v \mathrm{~N}-\mathrm{H}$ bands at around $3180-3263 \mathrm{~cm}^{-1}$, and other characteristic $v \mathrm{C}-\mathrm{H}, v \mathrm{CH}_{3}, v \mathrm{C}-\mathrm{C}, v \mathrm{Cd}-\mathrm{N}, v \mathrm{C}=\mathrm{N}$ bands in the expected regions (Table 1). The complex $[\mathrm{CdLI}]\left(\mathrm{ClO}_{4}\right)$ shows the perchlorate bands around 1107 and $613 \mathrm{~cm}^{-1}$ (Table 1). The perchlorate group is ionic in the complex, since there is no splitting of the perchlorate band (Roy and Bembi, 2005) around $1100 \mathrm{~cm}^{-1}$. The IR spectrum for the complex $\left[\mathrm{CdL}\left(\mathrm{ClO}_{4}\right)\right]\left(\mathrm{ClO}_{4}\right)$ exhibits bands at $1130,1070,1024$ and $621 \mathrm{~cm}^{-}$ ${ }^{1}$; the complexes [Cd(tet-a) $\left.\left(\mathrm{ClO}_{4}\right)_{2}\right]$ and $\left[\mathrm{Cd}\left(\right.\right.$ tet-b) $\left.\left(\mathrm{ClO}_{4}\right)_{2}\right]$ exhibit bands at $1125,1070-1080,1037-1051$ and $624 \mathrm{~cm}^{-1}$; due to the perchlorate group. The splitting of the perchlorate at $1100 \mathrm{~cm}^{-1}$ is an indication of presence of coordinated $\mathrm{ClO}_{4}^{-}$(Roy, et al., 1999). The IR spectrum of the complexes cis$\left[\mathrm{Cd}(\right.$ tet-a $\left.)\left(\mathrm{NO}_{3}\right)\right]\left(\mathrm{NO}_{3}\right)$ and cis-[Cd(tet-b)( $\left.\left(\mathrm{NO}_{3}\right)\right]\left(\mathrm{NO}_{3}\right)$ display bands attributed to the coordinated $\mathrm{NO}_{3}{ }^{-}$group (Table 1). Thus, the pattern centered at $1374-1375 \mathrm{~cm}^{-1}$ of cis-[Cd(tet-a) $\left.\left(\mathrm{NO}_{3}\right)\right]\left(\mathrm{NO}_{3}\right)$ and cis-[Cd(tetb) $\left.\left(\mathrm{NO}_{3}\right)\right]\left(\mathrm{NO}_{3}\right)$ are splitted into bands at $1278-1284$ and $1458-1466 \mathrm{~cm}^{-1}$; the pattern with the separation of these bands by $180-182 \mathrm{~cm}^{-1}$ respectively being consistent with a bidentate mode of coordination (Roy, et al., 2010). The bands at $720-738$ and $808-823 \mathrm{~cm}^{-1}$ of these complexes support the presence of an ionic nitrate (Hazari, et al., 1997). Since IR spectra of these compounds could not be run at a range lower than $400 \mathrm{~cm}^{-1}$, Cd-I, Cd-Cl bands could not be recorded. 
Table 1. IR spectral data* $\left(\mathrm{cm}^{-1}\right)$ for complexes.

\begin{tabular}{|c|c|c|c|c|c|c|c|}
\hline $\begin{array}{c}\text { Complex } \\
\text { No. }\end{array}$ & $v \mathrm{~N}-\mathrm{H}$ & $v \mathrm{C}-\mathrm{H}$ & $\mathrm{vCH}_{3}$ & $v \mathrm{C}-\mathrm{C}$ & $v \mathrm{Cd}-\mathrm{N}$ & $v \mathrm{C}=\mathrm{N}$ & Other bands \\
\hline 1 & $3250 \mathrm{~s}$ & $2937 \mathrm{~m}$ & $1360 \mathrm{vw}$ & $1170 \mathrm{vW}$ & $470 \mathrm{w}$ & $1583 \mathrm{~m}$ & $\begin{array}{c}1107 \mathrm{vs}, 613 \mathrm{~s}, \\
\mathrm{vClO}_{4}\end{array}$ \\
\hline 2 & 3219 m & $2978 \mathrm{~s}$ & $1375 \mathrm{vw}$ & 1163 w & $545 \mathrm{vw}$ & - & - \\
\hline 3 & 3219 m & $2980 \mathrm{~s}$ & 1376 vw & $1163 \mathrm{w}$ & $550 \mathrm{vw}$ & - & - \\
\hline 4 & $3226 \mathrm{~s}$ & $\begin{array}{c}2964 \\
\text { vs }\end{array}$ & 1380 vs & $1176 \mathrm{~s}$ & $532 \mathrm{vw}$ & - & $\begin{array}{c}738 \mathrm{~m}, 823 \mathrm{~m}, \\
1284 \mathrm{vs}, 1375 \\
\mathrm{vs}, 1466 \mathrm{~s} \\
\mathrm{vNO}_{3}\end{array}$ \\
\hline 5 & $3240 \mathrm{~m}$ & $2964 \mathrm{~m}$ & 1375 vs & 1165 m & $561 \mathrm{vw}$ & - & $\begin{array}{c}720 \mathrm{w}, 808 \mathrm{w}, \\
1278 \mathrm{~s}, 1374 \\
\mathrm{vs}, 1458 \mathrm{~m}, \\
\mathrm{vNO}_{3}\end{array}$ \\
\hline 6 & $3261 \mathrm{~m}$ & $2974 \mathrm{w}$ & $1370 \mathrm{Vw}$ & $1170 \mathrm{Vw}$ & $540 \mathrm{w}$ & $1616 \mathrm{~m}$ & - \\
\hline 7 & 3255 s & $2966 \mathrm{~m}$ & 1372 w & 1166 m & $563 \mathrm{vw}$ & - & - \\
\hline 8 & $3250 \mathrm{~m}$ & $2966 \mathrm{~m}$ & 1373 w & 1166 m & $560 \mathrm{vw}$ & - & - \\
\hline 9 & 3151 s & 2945 m & $1373 \mathrm{~s}$ & 1174 m & $536 \mathrm{vw}$ & $\begin{array}{l}1666 \\
\text { vs }\end{array}$ & $\begin{array}{c}1100 \mathrm{vs}, 621 \mathrm{~s}, \\
\mathrm{vClO}_{4}\end{array}$ \\
\hline 10 & $3190 \mathrm{~m}$ & $2980 \mathrm{~m}$ & $1386 \mathrm{~s}$ & 1197 m & $532 \mathrm{vw}$ & - & $\begin{array}{c}1110 \mathrm{vs}, 624 \mathrm{~s}, \\
\mathrm{vClO}_{4}\end{array}$ \\
\hline 11 & 3263 s & $2972 \mathrm{~m}$ & 1373 w & $1180 \mathrm{~s}$ & $520 \mathrm{w}$ & - & $\begin{array}{c}1110 \mathrm{vs}, 624 \mathrm{~s} \\
\mathrm{vClO}_{4}\end{array}$ \\
\hline 12 & $3211 \mathrm{~m}$ & $2962 \mathrm{~m}$ & $1380 \mathrm{~s}$ & 1166 w & $550 \mathrm{vw}$ & - & $\begin{array}{c}v C N 2071 \mathrm{~s}, \\
v \mathrm{CS} 750 \mathrm{vw}, \\
\delta \mathrm{NCS} 425 \mathrm{vw}\end{array}$ \\
\hline 13 & $\begin{array}{l}3203 \\
\text { vs }\end{array}$ & $2960 \mathrm{~s}$ & 1363 m & $1165 \mathrm{~s}$ & $532 \mathrm{vw}$ & - & $\begin{array}{c}\text { vCN } 2071 \mathrm{vs}, \\
\text { vCS } 767 \mathrm{w}, \\
\delta \mathrm{NCS} 420 \mathrm{vw}\end{array}$ \\
\hline 14 & $3196 \mathrm{~m}$ & $2970 \mathrm{~s}$ & 1370 w & $1180 \mathrm{w}$ & $\begin{array}{l}549 \mathrm{~m}, \\
432 \mathrm{~m}\end{array}$ & $1616 \mathrm{~s}$ & $\begin{array}{c}\text { vasym } 1465 \mathrm{~m}, \\
\text { vsym } 1335 \mathrm{vs}, \\
\delta \mathrm{NO}_{2} 835 \mathrm{~m}\end{array}$ \\
\hline 15 & $3180 \mathrm{~m}$ & $2968 \mathrm{~s}$ & 1375 w & $1184 \mathrm{w}$ & $\begin{array}{l}540 \mathrm{~m}, \\
432 \mathrm{~m}\end{array}$ & - & $\begin{array}{c}\text { vasym } 1460 \mathrm{~m}, \\
\text { vsym } 1332 \mathrm{vs}, \\
\delta \mathrm{NO}_{2} 835 \mathrm{~m}\end{array}$ \\
\hline
\end{tabular}

“-”, no band. *vs, very strong; s, strong; m, medium; w, weak; vw, very weak.

Though ${ }^{1} \mathrm{H}-\mathrm{NMR}$ spectra of some of these diamagnetic complexes could not be measured, the stereochemistry of these complexes have been assigned as corresponding dichloridocobalt(III) (Roy, et al., 2011) and corresponding zinc(II) (Yasmin, et al., 2013) complexes. This assignment is quite reasonable, because the ${ }^{1} \mathrm{H}-\mathrm{NMR}$ spectrum of our complexes (Table 2) showed the similar spectral pattern like that of corresponding dichloridocobalt(III) and corresponding zinc(II) complexes of our earlier studies.

${ }^{1} \mathrm{H}-\mathrm{NMR}$ spectra of complexes [CdLI] $\left(\mathrm{ClO}_{4}\right)$ and $[\mathrm{CdLCl}] \mathrm{Cl}$ display three $\mathrm{CH}_{3}$ singlets (Table 2). The singlet at $1.33-1.35 \mathrm{ppm}, 1.67-1.93 \mathrm{ppm}$ 
and 2.54-2.65 ppm can be assigned to methyl protons of equatorial components of gem-dimethyl groups, methyl protons of axial components of gem-dimethyl groups and protons of $\mathrm{CH}_{3}$ groups on $\mathrm{sp}^{2}$ carbon $\left(\mathrm{C}_{5} \& \mathrm{C}_{12}\right)$. Both the complexes display singlet at 2.31-2.50 ppm attributable to $4 \mathrm{H}$ of two $\mathrm{CH}_{2}$ groups on $\mathrm{C}_{6}$ and $\mathrm{C}_{13}$. They also display multiplte at 3.49-3.60 ppm due to other $\mathrm{CH}_{2}$ and singlet at 7.74-8.58 ppm for $\mathrm{NH}$ groups (Table 2).

${ }^{1} \mathrm{H}-\mathrm{NMR}$ spectra of all three complexes of ligand 'tet-a' trans[Cd(tet-a) $\left.\mathrm{I}_{2}\right]$, cis- $\left[\mathrm{Cd}\left(\right.\right.$ tet-a) $\left.\left(\mathrm{NO}_{3}\right)\right]$ and $\left[\mathrm{Cd}\left(\right.\right.$ tet-a) $\left.\left(\mathrm{ClO}_{4}\right)\right]$ show a sharp methyl singlet at 1.21-1.25 ppm corresponding to the methyl protons of axial components of gem-dimethyl groups. The multiplet at 1.15-1.20 ppm corresponding to $12 \mathrm{H}$ can be assigned to a singlet $(6 \mathrm{H})$ arising out of equatorial components of gem-dimethyl group overlapped with the doublet (6H) arising out of equatorially oriented methyl protons on $\mathrm{C}_{5}$ and $\mathrm{C}_{12}$ chiral carbons. Similarly the complexes cis-[Cd(tet-b) $\left.\left(\mathrm{NO}_{3}\right)\right]\left(\mathrm{NO}_{3}\right)$ and $[\mathrm{Cd}($ tetb) $\left(\mathrm{ClO}_{4}\right)_{2}$ ] displays two methyl singlets corresponding to $6 \mathrm{H}$ of equatorial methyl, two siglet corresponding to $6 \mathrm{H}$ of axial methyl of gem-dimethyl group, and one doublet corresponding to equatorial methyls at two chiral carbons. Except cis-[Cd(tet-a) $\left.\left(\mathrm{NO}_{3}\right)\right]\left(\mathrm{NO}_{3}\right)$ and cis- $\left[\mathrm{Cd}\left(\right.\right.$ tet-b) $\left.\left(\mathrm{NO}_{3}\right)\right]\left(\mathrm{NO}_{3}\right)$ all the complexes of 'teta' and 'tetb' show a multiplte corresponding to $4 \mathrm{H}$ of $\mathrm{CH}_{2}$ groups on $\mathrm{C}_{6}$ and $\mathrm{C}_{13}$ position. In case of complexes cis-[Cd(teta) $\left.\left(\mathrm{NO}_{3}\right)\right]\left(\mathrm{NO}_{3}\right)$ and cis- $\left[\mathrm{Cd}\left(\right.\right.$ tet-b) $\left.\left(\mathrm{NO}_{3}\right)\right]\left(\mathrm{NO}_{3}\right)$ two doublets at 2.56-2.91 ppm and 2.97-3.18 ppm each corresponding to two protons can be assigned to two $\mathrm{CH}_{2}$ protons on two equivalent carbons on $\mathrm{C}_{6}$ and $\mathrm{C}_{13}$. Distorsion i.e. two doublets for two equivalent $\mathrm{CH}_{2}$ groups support the cis-configuration. All the complexes show different multipltes (Table 2) corresponding to other $\mathrm{CH}_{2}$ and a more downfield singlet at 7.21-7.50 ppm has been assigned to $\mathrm{NH}$ protons.

Table 2. ${ }^{1} \mathrm{H}-\mathrm{NMR}$ chemical shifts data (ppm) for the complexes

\begin{tabular}{cccc}
\hline $\begin{array}{c}\text { Complex } \\
\text { No. }\end{array}$ & $\begin{array}{c}\mathrm{CH}_{3} \text { signals } \\
\delta \text { ppm }\end{array}$ & $\begin{array}{c}\text { Signals for } \mathrm{CH}_{2} \text { on } \mathrm{C}_{6} \text { and } \mathrm{C}_{13} \\
\text { position } \\
\delta \text { ppm }\end{array}$ & $\begin{array}{c}\text { Other } \mathrm{CH}_{2} \text { and } \mathrm{NH} \\
\text { signals } \\
\delta \text { ppm }\end{array}$ \\
\hline 1 & $\begin{array}{c}1.33^{\mathrm{e}}(\mathrm{s}, 6 \mathrm{H}) \\
1.93^{\mathrm{a}}(\mathrm{s}, 6 \mathrm{H})\end{array}$ & $2.50(\mathrm{~s}, 4 \mathrm{H})$ & $3.49(\mathrm{~m}), 8.58(\mathrm{~s}, 2 \mathrm{H})$ \\
& $2.65^{\mathrm{e}}(\mathrm{s}, 6 \mathrm{H})$ & & $1.49(\mathrm{~m}), 2.20(\mathrm{~m})$ \\
2 & $1.21^{\mathrm{a}}(\mathrm{s}, 6 \mathrm{H})$ & $2.54(\mathrm{~m}, 4 \mathrm{H})$ & $7.48(\mathrm{~s}, 2 \mathrm{H})$ \\
& $1.20(\mathrm{~m})$ & & $1.51(\mathrm{~m}), 2.17(\mathrm{~m})$ \\
& $12 \mathrm{H})$ & $2.56(\mathrm{~d}, 2 \mathrm{H})$ & $3.06(\mathrm{~m}), 7.50(\mathrm{~s}, 2 \mathrm{H})$ \\
& $1.25^{\mathrm{a}}(\mathrm{s}, 6 \mathrm{H})$ & $2.97(\mathrm{~d}, 2 \mathrm{H})$ & $1.96(\mathrm{~m}), 2.36(\mathrm{~m})$ \\
& $1.18(\mathrm{~m})$ & & $3.05(\mathrm{~m}), 7.25(\mathrm{~s}, 2 \mathrm{H})$ \\
& $12 \mathrm{H})$ & $2.91(\mathrm{~d}, 2 \mathrm{H})$ & $3.60(\mathrm{~m}), 7.74(\mathrm{~s}, 2 \mathrm{H})$ \\
& $1.14^{\mathrm{e}}(\mathrm{s}, 6 \mathrm{H})$ & $3.18(\mathrm{~d}, 2 \mathrm{H})$ & \\
& $1.28^{\mathrm{a}}(\mathrm{s}, 6 \mathrm{H})$ & &
\end{tabular}


10

13
$11 \quad 1.29^{\mathrm{e}}(\mathrm{s}, 6 \mathrm{H})$

$2.54^{\mathrm{e}}(\mathrm{s}, 6 \mathrm{H})$

$1.24^{\mathrm{a}}(\mathrm{s}, 6 \mathrm{H})$

$1.15(\mathrm{~m}$,

$11 \quad 1.29^{\mathrm{e}}(\mathrm{s}, 6 \mathrm{H})$

$1.48^{\mathrm{a}}(\mathrm{s}, 6 \mathrm{H})$

$1.51^{\mathrm{e}}(\mathrm{s}, 6 \mathrm{H})$

$1.30^{\mathrm{a}}(\mathrm{s}, 6 \mathrm{H})$

$1.25(\mathrm{~m}$,

$12 \mathrm{H})$ $2.58(\mathrm{~m}, 4 \mathrm{H})$

$2.30(\mathrm{~m}, 4 \mathrm{H})$

$2.61(\mathrm{~m}, 4 \mathrm{H})$

$2.42(\mathrm{~s}, 4 \mathrm{H})$
1.53 (m), 2.21 (m)

$7.30(\mathrm{~s}, 2 \mathrm{H})$

$1.92(\mathrm{~m}), 2.04$ (m)

$7.21(\mathrm{~s}, 2 \mathrm{H})$

$1.59(\mathrm{~m}), 2.25(\mathrm{~m})$

$7.41(\mathrm{~s}, 2 \mathrm{H})$

3.05 (m), 7.25 (s, 2H)

Multiplicity is given as s, singlet; $d$, doublet; $\mathrm{m}$, multiplet. a = axial; e = equatorial.

The six coordinated octahedral trans-complexes, trans-[Cd(tet-a) $\left.\mathrm{I}_{2}\right]$, [Cd(tet-b) $\left.\mathrm{I}_{2}\right],\left[\mathrm{Cd}(\right.$ teta $\left.) \mathrm{Cl}_{2}\right],\left[\mathrm{Cd}\left(\right.\right.$ tet-b)Cl$\left.{ }_{2}\right],\left[\mathrm{Cd}\left(\right.\right.$ tet-a) $\left.\left(\mathrm{ClO}_{4}\right)_{2}\right]$ and [Cd(tetb) $\left(\mathrm{ClO}_{4}\right)_{2}$ ] show molar conductivity values (Table 3) of $0 \mathrm{ohm}^{-1} \mathrm{~cm}^{2} \mathrm{~mol}^{-1}$ in chloroform and 9-26 ohm $\mathrm{cm}^{-1} \mathrm{~mol}^{-1}$ in DMSO indicating that the complexes are non-electrolyte in nature, i.e. the anions are coordinated as expected for six-coordinated octahedral cadmium(II) compounds. All the cadmium(II) complexes of diene ligand $(\mathrm{L})$ : $[\mathrm{CdLI}]\left(\mathrm{ClO}_{4}\right), \quad[\mathrm{CdLCl}] \mathrm{Cl}$, $\left[\mathrm{CdL}\left(\mathrm{ClO}_{4}\right)\right]\left(\mathrm{ClO}_{4}\right)$, and the mononitratocadmium(II) nitrate complexes, cis$\left[\mathrm{Cd}(\right.$ tet-a $\left.)\left(\mathrm{NO}_{3}\right)\right]\left(\mathrm{NO}_{3}\right)$, cis- $\left[\mathrm{Cd}\left(\right.\right.$ tet-b) $\left.\left(\mathrm{NO}_{3}\right)\right]\left(\mathrm{NO}_{3}\right)$ show conductance values (Table 3) of 64-92 $\mathrm{ohm}^{-1} \mathrm{~cm}^{2} \mathrm{~mol}^{-1}$ in DMSO indicating that the complexes are 1:1 electrolytes as expected for the formulae assigned. The molar conductivity values of $196 \mathrm{ohm}^{-1} \mathrm{~cm}^{2} \mathrm{~mol}^{-1}$ and $168 \mathrm{ohm}^{-1} \mathrm{~cm}^{2} \mathrm{~mol}^{-1}$ in aqueous solution (Table 3) found for cis-[Cd(tet-b) $\left.\left(\mathrm{NO}_{3}\right)\right]\left(\mathrm{NO}_{3}\right)$ and [CdLCl]Cl respectively corresponding to $1: 2$ electrolytes are probably due to replacement of the coordinated nitrate or chloride ions by one or two molecules of water as shown by the following equations:

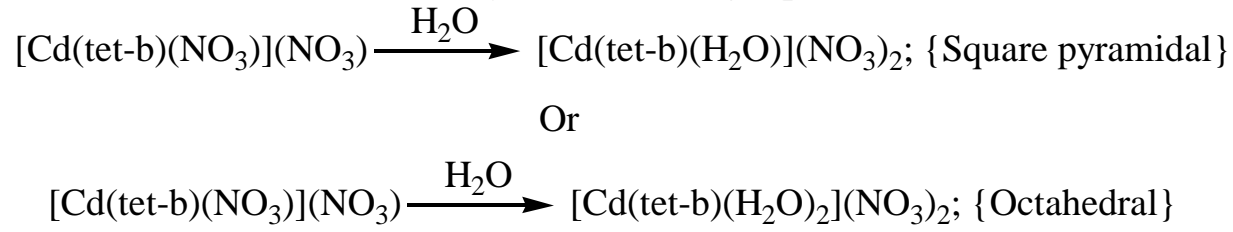

Or

$[\mathrm{CdLCl}] \mathrm{Cl} \stackrel{\mathrm{H}_{2} \mathrm{O}}{\longrightarrow}\left[\mathrm{CdL}\left(\mathrm{H}_{2} \mathrm{O}\right)\right](\mathrm{Cl})_{2} ;\{$ Square pyramidal $\}$

Or

$[\mathrm{CdLCl}] \mathrm{Cl} \stackrel{\mathrm{H}_{2} \mathrm{O}}{\longrightarrow}\left[\mathrm{CdL}\left(\mathrm{H}_{2} \mathrm{O}\right)_{2}\right](\mathrm{Cl})_{2} ;\{$ Octahedral $\}$ 
Similarly the conductance value of $214 \mathrm{ohm}^{-1} \mathrm{~cm}^{2} \mathrm{~mol}^{-1}$ of complex $\left[\mathrm{Cd}\right.$ (tet-b) $\left.\mathrm{Cl}_{2}\right]$ in aqueous solution corresponding to an 1:2 electrolyte which may be due to the replacement of two chloride ions by two $\mathrm{H}_{2} \mathrm{O}$ molecules. This replacement reaction can be expressed by the following equation:

$\left[\mathrm{Cd}(\right.$ tetb $\left.) \mathrm{Cl}_{2}\right] \stackrel{\mathrm{H}_{2} \mathrm{O}}{\longrightarrow}\left[\mathrm{Cd}(\right.$ tetb $\left.)\left(\mathrm{H}_{2} \mathrm{O}\right)_{2}\right](\mathrm{Cl})_{2} ;$ Octahedral $\}$ Table 3. Molar conductivity data* for complexes.

\begin{tabular}{cccc}
\hline Complex No. & \multicolumn{3}{c}{ Conductance $\left(\mathrm{ohm}^{-1} \mathrm{~cm}^{2} \mathrm{~mole}^{-1}\right)$ in different solvents } \\
\cline { 2 - 4 } & $\mathrm{CHCl}_{3}$ & DMSO & $\mathrm{H}_{2} \mathrm{O}$ \\
\hline 1 & - & 64 & - \\
2 & 0 & 09 & - \\
3 & 0 & 26 & - \\
4 & - & 66 & - \\
5 & - & 73 & 196 \\
6 & - & 69 & 168 \\
7 & 0 & 18 & - \\
8 & 0 & 17 & 214 \\
9 & - & 75 & - \\
10 & 0 & 21 & - \\
11 & 0 & 27 & - \\
12 & - & 90 & - \\
13 & - & 86 & - \\
14 & 0 & 20 & - \\
15 & 0 & 11 & - \\
\hline
\end{tabular}

“-”, not soluble. * Quoted values are mentioned after subtraction of conductance values of pure solvents.

Axial ligand substitution, axial substitution with anion exchange or simultanious addition \& substitution products

The concerned octahedral nitratocadmium(II) nitrate complexes, cis$\left[\mathrm{Cd}\left(\right.\right.$ tet-a) $\left.\left(\mathrm{NO}_{3}\right)\right]\left(\mathrm{NO}_{3}\right)$ and cis-[Cd(tet-b) $\left.\left(\mathrm{NO}_{3}\right)\right]\left(\mathrm{NO}_{3}\right)$ underwent axial ligand substitution reactions with subsequent anion exchange reactions with the KCNS to yield five coordinate square pyramidal complexes [Cd(teta)(SCN)](SCN) and [Cd(tet-b)(SCN)](SCN) respectively.

The complex trans-[Cd(teta) $\left.\mathrm{I}_{2}\right]$ underwent axial ligand substitution and the complex $\left.[\mathrm{CdLI}]\left(\mathrm{ClO}_{4}\right)\right]$ underwent simultaniously axial ligand substitution and addition reactions with the $\mathrm{NaNO}_{2}$ to yield [Cd(teta) $\left.\left(\mathrm{NO}_{2}\right)_{2}\right]$ and [CdL $\left.\left(\mathrm{NO}_{2}\right)_{2}\right]$ respectively. These cadmium(II) ligand substitution and addition products are found to be diamagnetic as expected for the presence of paired electron in their $\mathrm{d}^{10}$ system. The electronic spectra of these complexes also do not show d-d bands due to the $\mathrm{d}^{10}$ cadmium(II) but display charge transfer bands at 230 and $340 \mathrm{~nm}$.

The IR spectra of all the four complexes exhibit $v_{\mathrm{N}-\mathrm{H}}$ bands at around $3180-3211 \mathrm{~cm}^{-1}$, and other characteristic $v \mathrm{C}-\mathrm{H}, v \mathrm{CH}_{3}, v \mathrm{C}-\mathrm{C}, v \mathrm{Cd}-\mathrm{N}$ and $v \mathrm{C}=\mathrm{N}$ bands in the expected regions (Table 1). In case of square pyramidal 
complexes trans-[Cd(tet-a)(SCN)](SCN) and trans-[Cd(tet-b)(SCN)](SCN) appearance of sharp $\mathrm{vCN}$ bands in the region of 2071-2080 $\mathrm{cm}^{-1}$ is a good indication of S-bonded thiocyanate group (Farago and James, 1965). The two complexes display $v \mathrm{C}$-S bands at $750-767 \mathrm{~cm}^{-1} \delta \mathrm{NCS}$ bands at $420-425 \mathrm{~cm}^{-1}$ which do not correspond to ligands in this region and are therefore assigned for fully S-bonded thiocyanate group (Farago and James, 1965; Bembi, et al., 1991). Infrared spectra of the trans complexes trans-[CdL( $\left.\left(\mathrm{NO}_{2}\right)_{2}\right]$ and trans[Cd(tet-a) $\left(\mathrm{NO}_{2}\right)_{2}$ ] (Table 1) exhibit the vasym $\left(\mathrm{NO}_{2}\right)$ and vsym $\left(\mathrm{NO}_{2}\right)$ bands at $1465 \& 1460 \mathrm{~cm}^{-1}$ and $1335 \& 1332 \mathrm{~cm}^{-1}$ respectively. Appearance of a band at around $835 \mathrm{~cm}^{-1}$ can be attributed to $\delta \mathrm{NO}_{2}$ frequency and support the complexes to be $\mathrm{N}$-bonded nitro complexes.

The ${ }^{1} \mathrm{H}-\mathrm{NMR}$ spectrum of complex $[\mathrm{Cd}(\mathrm{tet}-\mathrm{a})(\mathrm{SCN})](\mathrm{SCN})$ shows a methyl singlet at $1.30 \mathrm{ppm}$ corresponding to the methyl protons of axial components of gem-dimethyl groups. The multiplate at $1.25 \mathrm{ppm}$ corresponding to $12 \mathrm{H}$ can be assigned to a singlet $(6 \mathrm{H})$ arising out of equatorial components of gem-dimethyl group overlapped with the doublet $(6 \mathrm{H})$ arising out of equatorially oriented methyl protons on $\mathrm{C}_{5}$ and $\mathrm{C}_{12}$ chiral carbons. Similarly the complex trans-[CdL $\left.\left(\mathrm{NO}_{2}\right)_{2}\right]$ displays three $\mathrm{CH}_{3}$ singlets (Table 2), one assignable to methyl protons of equatorial components of gem-dimethyl groups, other to methyl protons of axial components of gem-dimethyl groups and the 3rd one to protons of $\mathrm{CH}_{3}$ groups on $\mathrm{sp}^{2}$ carbon $\left(\mathrm{C}_{5} \& \mathrm{C}_{12}\right)$. Both the complexes display signals corresponding to $\mathrm{CH}_{2}$ and $\mathrm{NH}$ groups as expected (Table 2).

Molar conductivity values of 90 and $86 \mathrm{ohm}^{-1} \mathrm{~cm}^{2} \mathrm{~mole}^{-1}$ for complexes [Cd(tet-a)(SCN)](SCN) and [Cd(tet-b)(SCN)](SCN) respectively in DMSO indicate (Table 3) that these complexes are 1:1 electrolytes as expected for the formulae assigned. On the other hand molar conductivity values of 20 and $11 \mathrm{ohm}^{-1} \mathrm{~cm}^{2} \mathrm{~mole}^{-1}$ for complexes [CdL $\left(\mathrm{NO}_{2}\right)_{2}$ ] and [Cd(tet-a) $\left.\left(\mathrm{NO}_{2}\right)_{2}\right]$ in DMSO solution indicate (Table 3) that these complexes are non electrolyte as expected for the formula assigned.

\section{Conclusion:}

This study reveals that the concerned ligands undergo facile complexation with cadmium(II) to produce square pyramidal, trans and cis octahedral complexes when react with different cadmium(II) salts. In these cases, though both of $\mathrm{ClO}_{4}{ }^{-}$and $\mathrm{NO}_{3}{ }^{-}$could have acted as bidentate ligands, only $\mathrm{NO}_{3}{ }^{-}$acted as bidentate ligand to produce cis complexes, $\mathrm{ClO}_{4}{ }^{-}$acted as monodentate ligand to produce trans products. In one case one $\mathrm{ClO}_{4}{ }^{-}$did not coordinate at all. This study also shows that though $\mathrm{Cl}^{-}$could replace both $\mathrm{ClO}_{4}{ }^{-}$ions from ligand salt, $\mathrm{L} .2 \mathrm{HClO}_{4}$, $\mathrm{I}^{-}$could replace only one $\mathrm{ClO}_{4}{ }^{-}$group in one case, showing more ligating ability of $\mathrm{Cl}^{-}$compared to $\mathrm{I}^{-}$. Though 
$\mathrm{SCN}^{-}$is a linear and stronger ligand compered to $\mathrm{NO}_{3}^{-}$group, only one $\mathrm{SCN}^{-}$ group has been incorporated into the coordination sphere.

\section{Acknowledgement}

We are grateful to the Ministry of Education, People's Republic of Bangladsesh, for awarding a Research grant (Project no-24) to Professor Tapashi Ghosh Roy, Department of Chemistry, University of Chittagong, Bangladesh.

\section{References:}

Alborés, P., Slep, L. D., Weyhermüller, T., Rentschler, E. \& Baraldo L. M. (2006). Exchange coupling across the cyanide bridge: structural and DFT interpretation of the magnetic properties of a binuclear chromium(III) complex. Dalton. Trans., 7, 948.

Bembi, R., Drew, M. G. B., Singh, R. \& Roy, T. G. (1991). Polyazamacrocycles. 9. Characterisation of diastereoisomeric trans(Co( $\mathrm{Me}_{8}[14]$ ane $\left.) \mathrm{Cl}_{2}\right]^{+}$complexes. Inorg. Chem., 30, 1403.

Bembi, R., Bhardwaj, V. K., Sing, R., Taneija, K. \& Aftab, S. (1984). Synthesis and characterization of copper(II), nickel(II) and cobalt(III) complexes with 1,4,8,11-tetraazacyclohexadecane and 1,4,8,11tetraazacyclopheptadecane. Inorg. Chem., 23, 4153.

Biswas, F. B., Roy, T. G., Rahman, M. A. \& Emran, T. B. (2014). An in vitro antibacterial and antifungal effects of cadmium(II) complexes of hexamethyltetraazacyclotetradecadiene and isomers of its saturated analogue. Asian Pac. J. Trop. Biomed., 4(Suppl 2), 618.

Boss, J. F. (1984). Copper proteins and copper enzymes, CRC Press, $I$.

Busch, D. H., Farmery, K., Goedken, V. L., Katovic, V., Melnyk, A. C., Sperati, C. R. \& Tokel, N. (1971). Chemical foundations for the understanding of natural macrocyclic complexes. Advan. Chem. Ser.,100, 44. Chandra, S. \& Kumar, R. (2004). Synthesis and spectral studies on mononuclear complexes of chromium(III) and manganese(II) with 12membered tetradentate $\mathrm{N}_{2} \mathrm{O}_{2}, \mathrm{~N}_{2} \mathrm{~S}_{2}$ and $\mathrm{N}_{4}$ donar macrocyclic ligands. Trans. Met. Chem., 29, 269.

Escur, A., Vicente, R., Goher, M. A. S. \& Mautner, F. A. (1996). Synthesis and structural characterization of $\left.[\mathrm{Mn} \text { (ethylisonicotinate })_{2}\left(\mathrm{~N}_{3}\right)_{2}\right]_{\mathrm{n}}$, a twodimensional alternating ferro-antiferromagnetic compound. Magnetostructural correlations for the end-to-end pseudohalidemanganese system. Inorg. Chem., 35, 6386.

Farago, M. E. \& James, J. M. (1965). Coordination of thiocyanate and selenocyanate in some diamine complexes of nickel(II) and copper(II). Inorg. chem., 4, 1706. 
Ghachtouli, S. E., Cadiou, C., Déchamps-Olivier, I., Chuburu, F., Aplincourt, F. M., Patinec, V., Baccon, M. L., Handel, H. \& Roisnel, T. (2006). Nickel(II) complexes of cyclenand cyclam-pyridine: topological reorganisations induced by electron transfer. New J. Chem., 30, 392.

Goher, M. A. S., Abu-Youssef, M. A. M., Mauter, F. A. M. \& Popitsch, A. (1992). Preparation and structural characterization of catena- $\mu(1,3)$-azido- $\mu$ (O,N-picolinato)-aquamanganese(II),

$\mathrm{Mn}\left(\mathrm{NC}_{5} \mathrm{H}_{4} \mathrm{CO}_{2}\right)\left(\mathrm{N}_{3}\right)\left(\mathrm{H}_{2} \mathrm{O}\right)$.

Polyhedron, 11, 2137.

Hancock, R. D., Bhavan, R., Wade, P. W., Boeyens, J. C. A. \& Dobson, S. M. (1989). Ligand Design for complexation in aqueous solution. 1. Neutral oxygen donor bearing groups as a means of controlling size-based selectivity for metal ions. Inorg. Chem., 28, 187.

Hancock, R. D., Shaikjee, M. S., Dobson, S. M. \& Boeyens, J. C. A. (1988). The stereochemical activity or non-activity of the 'Inert' pair of electrons on Lead(II) in relation to its complex stability and structural properties. Some considerations in ligand design. Inorg. Chim. Acta., 154, 229.

Hazari, S. K. S., Roy, T. G., Nath, B. C., Roy, P. G., Ng, S. W. \& Tiekink, E. R. T. (2012). 5,7,7,12,14,14-Hexamethyl-4,11-diaza-1,8diazoniacyclotetradecane bis(perchlorate) monohydrate. Acta. Cryst., E68, 01179.

Hazari, S. K. S., Roy, T. G., Dey, B. K., Das, S. C. \& Tiekink, E. R. T. (1997). Synthesis, characterisation and antifungal activities of some new copper(II) complexes of isomeric 3,5,7,7,10,12,14,14-octamethyl-1,4,8,11tetraazacyclotetradecanes. Met. Based Drugs., 4(5), 255.

Lauffer, R. B. (1987). Paramagnetic metal complexes as water proton relaxation agents for NMR imaging: Theory and design. Chem. Rev., 87, 3786.

Mohapatra, R. K., Ghosh, S., Naik, P., Mishra, S. K., Mahapatra, A. \& Dash, D. C. (2012). Synthesis and characterization of homo binuclear macrocyclic complexes of $\mathrm{UO}_{2}(\mathrm{VI}), \mathrm{Th}(\mathrm{IV}), \mathrm{ZrO}(\mathrm{IV})$ and $\mathrm{VO}(\mathrm{IV})$ with schift-bases derived from ethylene diamine/orthophenylene diamine, benzilmonohydrazone and acetyl acetone. J. Korean Chem. Soc., 56(1), 62.

Notni, J., Görls, H. \& Anders, E. (2006). Zinc thiolate complexes [ZnLn(SR) $^{+}$with azamacrocyclic ligands: synthesis and structural properties. Eur. J. Inorg. Chem., 2006(7), 1444.

Radecka-Paryzek, W., Patroniak, V. \& Lisowski, J. (2005). Metal complexes of polyaza and polyoxa Schiff base macrocycles. Coord. Chem. Rev., 249, 2156.

Roy, T. G., Nath, B. C., Begum, K., Ng, S. W. \& Tiekink, E. R. T. (2011). trans-(5,7,7,12,14,14-Hexamethyl-1,4,8,11-tetraazacyclotetradeca-4,11diene-қ $\left.{ }^{4} \quad \mathrm{~N}, \mathrm{~N}^{\prime}, \mathrm{N}^{\prime \prime}, \mathrm{N}^{\prime \prime \prime}, \mathrm{N}^{\prime \prime \prime \prime}\right)$ bis(nitrite- $\quad$ қN)-cobalt(III) perchlorate hemihydrates. Acta. Cryst., 67, 1576. 
Roy, T. G., Hazari, S. K. S., Barua, K. K., Anwar, N., Zukerman-Schpector, J. \& Tiekink, E. R. T. (2010). Syntheses, characterisation and anti-microbial studies of cadmium(II) complexes containing 3,10-C-meso-Me ${ }_{8}[14] a_{\text {ane }}$ $\left(\mathrm{L}_{\mathrm{C}}\right)$. Appl. Organometal. Chem., 24, 878.

Roy, T. G., Hazari, S. K. S., Dey, B. K., Meah, H. A., Rahman, M. S., Kim, D. I. \& Park, Y. C. (2007). Synthesis, electrolytic behaviour and antimicrobial activities of cadmium complexes of isomers of 3,10-C-meso3,5,7,7,10,12,14,14-octamethyl-1,4,8,11-tetraazacyclotetradecane. J. Coord. Chem., 40, 1567.

Roy, T. G. \& Bembi, R. (2005). Synthesis, characterisation and polarographic studies of diastereoisomeric $\left[\mathrm{Cu}\left(\mathrm{Me}_{8}[14] \mathrm{ane}\right)\right]\left(\mathrm{ClO}_{4}\right)_{2}$ complexes. Ind. J. Chem., 44A, 700.

Roy, T. G., Hazari, S. K. S., Dey, B. K., Chakraborti, S. \& Tiekink, E. R. T. (1999). Synthesis, characterisation and antifungal activities of some new copper(II) complexes of octamethyl tetraazacyclotetradecadiene. MetalBased Drugs, 6(6), 345.

Sheikh, R. A., Shreaz, S., Khan, L. A. \& Hashmi, A. A. (2010). Synthesis, characterization and antifungal activity of transition metal complexes derived a novel macrocyclic compartmental ligand. J. Chem. Pharm. Res., 2(3), 274. Suh, M. P., Moon, H. R., Lee, E. Y. \& Jang. S. Y. (2006). A redox-active twodimensional coordination polymer: preparation of silver and gold nanoparticales and crystal dynamics on guest removal. J. Am. Chem. Soc., 128(4), 4710.

Yasmin, S., Suarez, S., Doctorovich, F., Roy, T. G. \& Baggio, R. (2013). Three transition-metal complexes with the macrocyclic ligand meso5,7,7,12,14,14-hexamethyl-1,4,8,11-tetraazacyclotetradecane

(L): $\left[\mathrm{Cu}\left(\mathrm{ClO}_{4}\right)_{2}(\mathrm{~L})\right],\left[\mathrm{Zn}\left(\mathrm{NO}_{3}\right)_{2}(\mathrm{~L})\right]$ and $\left[\mathrm{CuCl}(\mathrm{L})\left(\mathrm{H}_{2} \mathrm{O}\right)\right] \mathrm{Cl}$. Acta. Cryst., 69, 862. 